\title{
Response
}

\section{A response from Amy Plantinga Pauw}

In his review of my book, Steven Studebaker asserts that Jonathan Edwards’s trinitarianism is useful in challenging 'the common assumption that Western Augustinian trinitarianism is inherently monistic and must be transcended by recourse to the Eastern trinitarian tradition'. While I find Edwards to be theologically useful for a wide variety of reasons, I am in basic agreement with Studebaker's assertion, and certainly do not share in the 'common assumption' about Augustinianism that he deplores.

In the years since I worked with Edwards's trinitarian theology for my dissertation, the work of Michel René Barnes and Sarah Coakley, among others, has helped me unlearn facile distinctions between the 'threeness' of Cappadocian trinitarianism and the 'oneness' of Augustinian trinitarianism. With Studebaker, I am all for rescuing Augustine from a flat, monochromatic reading of him as a purveyor of divine 'oneness'. The treatment of Augustine's thought in certain strands of twentieth-century trinitarianism is in my view so distorted as to border on libel. Rather than opposing Eastern and Western views of the trinity, I argue in my book that the Augustinian legacy was a multiform one from the beginning, easily giving rise to both social and psychological themes (clumsy labels, I admit). Edwards, in my reading, reflects this complex tradition. There is very little attention to the Cappadocian tradition in my book, to which even a quick glance at the index testifies. I certainly do not valorize Eastern (or Victorine) 'threeness' trinitarianism at the expense of Western 'oneness' trinitarianism. I am instead intent on recovering the complexity of Western trinitarian thought in the interests of a more adequate interpretation of Edwards's theology.

To that end, I examine Edwards's modulations between two models of the trinity: a model that depicts the Son and Spirit as the wisdom and love of God, and a model that depicts the trinity as, in Edwards's phrase, 'a family of the three'. I loosely associate the former with Augustine and the latter with the twelfth-century Western theologian Richard of St Victor - who cannot be understood apart from his formation in the broadly Augustinian tradition. While I try not to overplay the differences between 'oneness' and 'threeness' trinitarianism, my point is that Western trinitarian tradition is more complicated than it is sometimes portrayed to be, and that Edwards reflects the richness and the tensions of this theological inheritance. The 'supreme harmony' of his trinitarian reflection is achieved by his skillful uses and adaptations of these two models in the service of his larger theological project of narrating God's great work of redemption. 
By contrast, Studebaker's thesis is that Jonathan Edwards consistently employed 'the Augustinian mutual love model' of the trinity, a model that represents the Holy Spirit as the mutual love of the Father and the Son. In my book I pay attention to the social valences of this model, and assert that it is 'the characteristic mode in which Edwards employed the psychological image' of the trinity. ${ }^{1}$ So it is simply incorrect to say that I 'presuppose that the Western Augustinian tradition cannot accommodate social categories'. The question is whether Studebaker's smooth, homogeneous reading of Edwards's trinitarianism is warranted. Here is where our main disagreement lies.

Studebaker is right that this mutual love model of the trinity is pervasive in Edwards's trinitarian thought, and I could have stated this more clearly in my book. I might go so far as to call it Edwards's default trinitarian model. But I find key strands of Edwards's trinitarianism that do not fit easily within this model. For example, much of the linkage between creation and redemption in Edwards's theology depends on the depiction of the Son as the wisdom or knowledge of God, not as one bound to the Father in mutual love. In these contexts, Edwards depicts God as the 'fullness of every perfection, of all excellency and beauty, and of infinite happiness', whose eternal desire is to 'communicate himself to creatures' by effusions of divine wisdom and love. I do not find the mutual love model helpful in illuminating Edwards's trinitarianism here. Conversely, Edwards's stalwart defense of the term 'person' to mark 'the distinction of the Eternal Three' and his depiction of the trinity as 'a family of the three' are not helpfully illuminated by the mutual love model either. Edwards's argument that 'there must be a plurality in God', because the Johannine affirmation that " God is love" shows that there are more persons than one in the Deity', is more reminiscent of Richard of St Victor's trinitarian vocabulary and emphasis than that of Augustine himself. In short, while Edwards often depicted the Father and the Son as bound together by the love of the Holy Spirit, this single model does not adequately reflect the complexity of his trinitarianism.

Edwards considered the doctrine of the trinity 'useful' in showing the way 'of living to God through Christ'. This was the focus of his interest in trinitarian doctrine. He did not seem particularly concerned about systematic consistency in his doctrinal articulations. Instead - just as Augustine had done-Edwards gloried in the variety of mutually correcting trinitarian resources at his disposal in the service of a creative theological exploration

1 Amy Plantinga Pauw, 'The Supreme Harmony of All': The Trinitarian Theology of Jonathan Edwards (Grand Rapids, MI: Eerdmans, 2002), 45. All subsequent quotations from Edwards will be drawn from this book. 
of God's work of redemption. Rather than denying or ignoring the points of tension in Edwards's trinitarianism, I find in these intersections fruitful places for theological reflection. For example, why did Edwards conclude that adequately portraying God's work of redemption required different ways of portraying the Godhead? Why is the Holy Spirit both so central and so problematic in his pastoral reflections? Rather than trimming and folding in the edges of Edwards's trinitarianism to fit neatly within the confines of a single trinitarian model, I find it more interesting to listen for both the complex theological harmony he achieved and its occasional discordant notes.

Studebaker also finds Edwards to be much more securely within the theological tradition of divine simplicity than I do. We have the same evidence before us, but we read it differently. When I compare Edwards with his Puritan and Reformed scholastic influences, his approach to this tradition seems idiosyncratic. 'If a man should tell me', Edwards declared, 'that the immutability of God is God or that the omnipresence of God and authority of God, is God, I should not be able to think of any rational meaning of what he said.' How could someone firmly within the simplicity tradition express bewilderment at the identification of God's attributes with God's being? In his employment of the covenant theology tradition, Edwards abandoned the doctrine of inseparable operations of the Godhead, another cornerstone of the simplicity tradition. Whereas his theological guide Francis Turretin had warned that 'simplicity and triplicity are opposed to each other, and cannot subsist at the same time', Edwards confidently asserted a 'triplicity in God, three that cannot be confounded'. While Studebaker and I agree that Edwards explicitly appealed to the simplicity tradition and assumed it in places, I conclude that Edwards was also clearly willing to flout it. Rather than homogenize his theology by ignoring this fact, I prefer to explore the pressures that Edwards's larger philosophical and theological reflections brought to bear on his use of the divine simplicity tradition.

As Douglas Sweeney has affirmed, 'Edwards was an occasional rather than a systematic thinker. He did not present his theology in a well-wrapped package, with all its loose ends neatly tied up. His thought emerged from his pastoral labors, from his love affair with the Bible, and from the heat of controversy.' ${ }^{2}$ I would venture to say much the same thing for Augustine. Careful theological consistency has not been a cardinal virtue of theologians like these. While Studebaker's review challenges me to go back and examine whether I have overemphasized ambivalence, paradox, and conflict in Edwards's

2 Douglas A. Sweeney, Nathaniel Taylor, New Haven Theology, and the Legacy of Jonathan Edwards (Oxford, 2003), 11. 
trinitarianism, I should say that I do not regard these automatically as theological failings. I am much more worried about attempts to tidy up rich and multivalent theologies like those of Augustine and Edwards, for purposes either of condemnation or commendation. Edwards well understood that the 'supreme harmony' he discerned in the eternal life of the Godhead could be only imperfectly captured in theological formulations. The trinity remained for him, as it did for Augustine, 'an incomprehensible mystery, the greatest and the most glorious of all mysteries'. And that is one reason why the trinitarian reflections of both Edwards and Augustine continue to spark Christian imagination and bear new theological fruit.

Amy Plantinga Pauw

Louisville Presbyterian Theological Seminary, 1044 Alta Vista Road, Louisville, Kentucky 40205

amypauw@lpts.edu 